\title{
Surgical strategy for coronary artery aneurysms
}

\author{
M Hibino ${ }^{*}$, K Tajima, K Uchida, H Munakata, K Fujii, W Kato, Y Takami, Y Sakai \\ From 23rd World Congress of the World Society of Cardio-Thoracic Surgeons \\ Split, Croatia. 12-15 September 2013
}

\section{Backgrounds}

Coronary artery aneurysms (CAA) are relatively rare diseases caused by kinds of backgrounds such as atherosclerosis and connective tissue disorders, and the surgical strategy of them is still controversial. We have performed aneurysmectomy when the diameter is more than $10 \mathrm{~mm}$ or CABG when the stenosis exists around the CAA. In this study, we evaluated our result of the strategy.

\section{Methods}

Between 2002 and 2012, 10 patients (7 male, 68.7 \pm 13.0 yr) with CAA (6 LMT, 3 LAD, 1 RCA) had cardiac operations in our hospital. The mean size of the CAA was 20.2 (7 to $51 \mathrm{~mm}$ ). 7 CAA were saccular aneurysms, 2 were due to BWG syndrome and post PCI complication, respectively.

\section{Results}

6 patients with more than $10 \mathrm{~mm}$ CAA received aneurysmectomy and 6 patients with stenosis received CABG to the distal artery of CAA. Other concomitant procedures included MVP and AVR. The operative complications included 2 branch artery occlusions, but 1 was protected by CABG. There were no hospital death, and no CAA related event in $2.4 \pm 2.5$ follow-up. In the postoperative CAG, there were no residual aneurysms after aneurysmectomy.

\section{Conclusions}

Our surgical strategy for CAA was feasible. We need to pay attention to the branch occlusion in case of aneurysmectomy.

Published: 11 September 2013

* Correspondence: mhibino@nagoya2.jrc.or.jp

Cardiovascular Surgery, Nagoya Daini Red Cross Hospital, Nagoya, Japan
doi:10.1186/1749-8090-8-S1-0180

Cite this article as: Hibino et al:: Surgical strategy for coronary artery

aneurysms. Journal of Cardiothoracic Surgery 2013 8(Suppl 1):0180.
Submit your next manuscript to BioMed Central and take full advantage of:

- Convenient online submission

- Thorough peer review

- No space constraints or color figure charges

- Immediate publication on acceptance

- Inclusion in PubMed, CAS, Scopus and Google Scholar

- Research which is freely available for redistribution
() Bïomed Central 